\title{
Culture of Life-support of the Tungus: the Practice of Reindeer Herding, Contemporary Adaptive Strategies and New Challenges
}

\author{
Sardaana A. Alekseeva* \\ The Institute for Humanities Research \\ and Indigenous Studies of Siberian Branch North \\ of Russian Academy of Sciences (Yakutsk), \\ 1 Petrovskogo Str., Yakutsk, 677007, Russia
}

Received 24.04.2016, received in revised form 17.06.2016, accepted 04.09.2016

This article is devoted to regards the actual problems of cultural livelihoods of Indigenous Peoples of the North-East of Russia, in particular, the traditional practice of reindeer herding of the Tongues, contemporary consideration of adaptive coping strategies and new opportunities in the context of globalization. The work on the basis of the method of expeditionary field work subjected to scientific analysis of the specifics of nomadic reindeer culture of the peoples of the North (for example, the Evens and Evenki), which marked the structural uniformity of phenomena such as the trajectory of continuous movement "feeding the landscape" (pet or wild animal), the cycle paths of movement of human groups within the range of nomadic and economic structure-phenological calendar. Spacetime representation, captured in the traditional calendar, and structural uniformity of the economic cycle, the structure of livelihoods and culture are reflected in the picture of the world of the studied ethnic groups. Reindeer hunters, that move during the hunting year, within a closed circle route, developed a "circular" model of life in contrast to the "linear" type of culture of life support (semisettled fishermen, whose route ran along the main feeding substance - river). Today we can talk about more or less sustainable model of cultural livelihoods of Indigenous Peoples, which is characterized by a combination and synthesis of modern (urban) elements and archaic (northern) cultures. Installing problem identified the following three main lines of research: traditional and modern practices in the conduct of reindeer hunting and fishing in life-support system of the peoples of the Tungus; the main options for the economic models of life of the peoples of the North; reconstruction of ethnolocal options for livelihoods of the Tungus. Currently, different ethnolocal groups of indigenous peoples has developed a range of livelihood strategies, which are important not only historical and cultural meanings, but also social and economic factors.

Keywords: cultural livelihoods, herding, indigenous peoples of the North, Tungus, «accommodating» the landscape, adaptability, reindeer culture, traditional model of economic, local option for life support, ethnic identity.

DOI: 10.17516/1997-1370-2016-9-10-2305-2314.

Research area: ethnography, ethnology and anthropology.

(C) Siberian Federal University. All rights reserved

* Corresponding author E-mail address: alexeeva_sar@mail.ru 


\section{Introduction}

In the world of science formulated the basic conceptual positions and algorithm research in the field of design models of life, there is considerable experience in the study of natural and environmental aspects of local systems, including indigenous peoples. Each study of regional or local culture is a definite contribution to the development of a global model of society and to study the extent of his influence on the ability of adapting the environment. It should be noted that the study developed by mankind in the Arctic ways to ensure at this stage of life is becoming increasingly important and popular.

The Russian scientific studies on traditions of life-support of ethnic group gained the comprehensive and systematic approach, including both physical (biological) survival and socio-cultural aspects of interaction with the territory, in contrast to the Western tradition of focusing political factors of livelihood, as well as the integration of modes of production and ethnic identities.

The works on the system and synergistic analysis are Fundamental for the formulation of the concept of the study (M.S.Kagan, E.S.Markarian, V.P.Branski, etc.)The research of representatives of ethno cultural approach (E.S.Markarian, Y.I. Mkrtumyan, S.A.Arutyunov, etc.) It is important to emphasize the works of A.V. Golovnevin anthropology movement, mobility of Arctic, the potential of the north of nomadism and "design" in the practice of modern nomads of Arctic exploration.

Questions natural-ecological and socioeconomic adaptation of the studied peoples, and ethnogenesis and ethnic history on the material culture of life support objects are discussed in publications of I.S. Gurvich, V.A. Tishkov, S.M. Shirokogorov, G.M.Vasilevich, A.B. Spevakovsky, V.A. Tugolukov, U.B. Simchenko, A.M. Zolotarev, M.G. Levin, M.G.
Turov, V.V. Karlov, L.R. Pavlinsky, V.A. Turaev, V.I. Dyachenko, N.V. Yermolov, K.B. Klokov, V.A. Kozmin, A.M. Pevnov, U.G. Popova, N.I. Novikova, A.A. Syrina, L.I. Missonova, A.N. Yamskov, V.N. Davydov, N.I. Novikova, U.A. Vinokurova, A.A. Alexeev, E.K. Alexeeva, etc.

This research meets the basic trends of modern historiography: the interest in the territories of the Russian North remains high worldwide and is currently. In recent decades, the Arctic becomes the object of attention from both domestic and foreign researchers. The international community realized the place and role of the Arctic and the North in the solution of global problems of all mankind, acknowledged the high human value of original culture of the Arctic peoples. In modern scientific literature the study of the problems of the Arctic and the North becomes one of the priority directions in the development of global human knowledge. Actively continue to work on these problems, and researchers from the Institute of Polar studies. R. Scott, University of Cambridge (UK), as well as individual research centers, and a separate group of researchers from France, Germany, USA, Japan, Poland, Estonia, Finland, etc.

The scientific novelty of the project lies in the fact that this is the first interdisciplinary, comprehensive study undertaken on cultural livelihoods of Indigenous Peoples of the NorthEast of Russia, in particular, traditional and modern practices of reindeer herding on the example of the Evens and Evenki their new adaptive strategies for survival in the face of deepening globalization.

The novelty of the project caused by the involvement and interpretation of chronologically and geographically new interdisciplinary materials, as well as possibilities of practical use of the new results obtained in the further knowledge of the Northeast of Russia. 


\section{Theoretical framework}

New conceptual level of development of the theme requires qualitatively new methodological approaches in terms of modern science as a domestic, foreign, expanding research field at the level of interdisciplinary techniques based on bringing cross-cultural theoretical developments.

Holistic study of life-support systems as a means of human activity involves an appeal to a number of fundamental methodological approaches that in total can identify certain patterns of functioning of the research object.

The methodological basis and conceptual construction work largely determines the systemsynergetic approach that allows to study the object in a broad of historical and cultural and areal contexts. System synergetic approach to the study of life support systems of the North as the adaptation of the system allows a new level of understanding of the material to generalize the data of ethnography, history, cultural studies, sociology, lay the foundation in the study of ethnic cultures of the North. This approach also allows submitting the material in integrative and broad historical, territorial and socio-cultural aspects. Finally, the culture of life support appears as a managed through internal biosocial, economic, political and ritual and symbolic mechanism of controlling the maintenance and reproduction of life.

Methodological significance is the potential of comparing, in particular, the use of methods such as comparative-typological, comparative benchmarking, historical and genetic, allows you organize and build structural components of the object of study in the synchronic and diachronic plans. Analysis of the research approaches to the study of the culture of life-support systems of the local output illustrated humanitarian component of cultural studies on a different stage of the analysis and synthesis of regional ethnic cultures. Overview of the conceptual base for the study of cultural livelihood and building a system-synergetic approach to the analysis of cultural systems has shown that accumulated within these scientific paradigms experience can be used in further study of the functioning, the historical culture change of livelihoods of Indigenous Peoples of the North-East of Russia and forecasting scenario for development.

\section{Statement of the problem}

The research aims to study the actual problems of cultural livelihoods of Indigenous Peoples of the North-East of Russia, in particular, the traditional practice of reindeer herding, contemporary consideration of adaptive coping strategies and new opportunities in the context of globalization. The work on the basis of the method of expeditionary field work will be subjected to scientific analysis of the specifics of nomadic reindeer culture of the peoples of the North (for example, the Evens and Evenki), which marked the structural uniformity of phenomena such as the trajectory of continuous movement "feeding the landscape" (pet or wild animal), the cycle paths of movement of human groups within the range of nomadic and economic structure-phenological calendar. Space-time representation, captured in the traditional calendar, and structural uniformity of the economic cycle, the structure of livelihoods and culture are reflected in the picture of the world of the studied ethnic groups. Reindeer hunters, that move during the hunting year, within a closed circle route, developed a "circular" model of life in contrast to the "linear" type of culture of life support (semi-settled fishermen, whose route ran along the main feeding substance - river). Today we can talk about more or less sustainable model of cultural livelihoods of Indigenous Peoples, which is characterized by a combination and synthesis of modern (urban) elements and archaic (northern) cultures. 
Installing problem identified the following three main lines of research: traditional and modern practices in the conduct of reindeer hunting and fishing in life-support system of the Tungus; the main options for the economic models of life, reconstruction of ethnolocal options for livelihoods of the Tungus.

\section{Research methods}

We used specifically the following ethnographic methods: participant observation method and in-depth interviews.

The method of participant observation as a research practice that characterizes the classic ethnographic tools. Participant observation refers to the number of qualitative research methods, allowing to study people in their natural environment, in everyday life situations. It is a form of field research in which the researchers are directly involved in the activities of the team as an observer and participant of the communicative act.

In-depth interview is an informal personal interview conducted by the interviewer according to the prearranged plan and is based on the use of techniques encouraging the respondents to long and detailed discussions on the researcher is interested in range of issues. The interview is conducted one-on-one and lasts approximately 30 to 60 minutes. During the interview explores the personal opinion of the Respondent, his beliefs and values.

Conducting in-depth and expert interview refers to qualitative research methods. The main difference between qualitative from quantitative methods is that in the first case, data are collected from a relatively small group of respondents and not analyzed with statistics, while when using quantitative methods is investigated a large group of people, and the data are then analyzed using statistical methods.

\section{Discussion}

For centuries reindeer herding was the basis for the economic life of the indigenous peoples of the North and is the original form of human adaptation to life in the extreme conditions of the North. The interaction between human and nature generated by indigenous peoples of the North is a unique experience that deserves study and full support.

As a result of the interdisciplinary study of complex cultural livelihood culture Researching of herding culture of the peoples of the North is one of the most actual problems of both science and cultural-educational practice. This is an important component of the life support systems of Indigenous Peoples of the North-Eastern part of Russia - a region that plays a significant role in the future sustainable economic and cultural development of the Russian Federation: on the one hand - a powerful natural resources; on the other hand - the conservation of forms of traditional ethnic culture, which have a high level of adaptation to extreme climatic conditions.

As the most stable form of life of indigenous peoples of the North, Reindeer herding culture can be considered as one of the most historically stable phenomena in world culture. Reindeer is still one of the fundamental values as a factor in the preservation of culture, being the main means of expressing cultural identity, ethnic identity.

Reindeer - questions about time and the ways of its domestication (domestication), including the Northern ethnic groups, the relationship between humans and deer, wild and domestic reindeer, resulting from this symbolic representation - can cause the natural interest, remain relevant and in demand in the Western and domestic science (Willerslev, Vitebsky, Alexeev 2015: 1-31).

In scientific literature there is no consensus about the origin of reindeer. The first mention of reindeer herding in Europe contains Karelian epos "Kalevala". Petroglyphs of Karelia and cave 
dwellings in France indicate that in the era of late-glacial reindeer was hunted. Judging by the results of archaeological excavations of burial Syrskoye (R. Tour, Yenisei basin), Afontovo mountains (near Krasnoyarsk), rock carvings and «deer» stones of the Baikal region, Altay and Northern Mongolia, reindeer herding was widespread in Central Asia.

Reindeer - herd animals, constantly migrating from North to South, so the researchers believe that the first primitive hunters were forced to move following the herds, knowing that these animals are source of food and clothing (Alekseev A, 2006: 84).

Questions about the time and the ways of reindeer's domestication, inclusion in the supplying system of the northern ethnic groups, the relationship between humans and deer, wild and domestic reindeer, arising out of this symbolic representations cause natural interest, and remain relevant in Western and domestic Science.

In this regard, the allocation of herding culture as an independent cultural object looks methodologically justified.

The birthplace of reindeer is considered to be North America. Other authors suggested the initial emergence of reindeer herding in two centers - Sayan (Sayano-Altai highlands) and the Tungus (mining areas of Transbaikalia and the Amur region), where different peoples extended it to the North of Asia and Europe. First and foremost the reindeer herding mastered the taiga and mountain-taiga zone and in the tundra zone they appeared much later. Currently, worldwide there are more than 2 million heads of deer. Domesticated reindeer are bred sway on the territory of the Russian far North, in the Scandinavian countries (Finland, Sweden, Norway), Greenland, Alaska, Canada.

In socio-economic terms, herding, and fishing out promise indigenous peoples to the Soviet government presented unique complex structure, which ensured the survival of Northern peoples in the extreme conditions of nomadic life in tundra, mountain taiga, taiga zones.

Before the revolution, the most important legal act was the «Charter on the management of foreigners 1822,» where the Foundation of self and the subject of land tenure were recognized as tribal and neighboring community. The nomadic "other people" did not have private ownership of land, they enjoyed the right of ownership (communal ownership). In pre-revolutionary Russia (1912) was only 1674 thousand head of deer.

After the establishment of Soviet power socio-economictransformationhasfundamentally turned the traditional way of life of the peoples of the North. In the 1920-ies, after the establishment of the new government were established following the authorities as tribal councils, tribal meetings, indigenous regional congresses and Executive committees (RECS). The land became the property of the state, since the 1930 s, there has been a dispossession reindeer - owners and on the basis of associations and cooperatives were created by the collective reindeer herding farms. In 1926-1927 according to the results of the Polar census and farms in the far North of Russia, the number of reindeer was 2202,7 thousands.

Relations between the state and indigenous peoples for reindeer herding, in different historical periods were notable for their instability. Evaluation of reindeer was highly controversial and politicized. It is reflected in the policy of the transition to the settled way of life, fundamental reform of the economy of indigenous peoples in the early twentieth century, and in the transition to business practices borrowed from other neighboring nations. As a result, the loss of deer, limited mobility, reducing of the size of land due to reasons of a different nature have catalyzed the growth of deficiency of appropriating economic practices and led to the search of other coping 
strategies. Strengthening political and economic leverage over the traditional way of life of Indigenous Peoples became noticeable in the 1930s. In the Soviet period, the sustainability of the ethnic groups in the North-East was disrupted as a result of collectivization and socialization of reindeer, the transfer policy of the nomadic population in the sedentary, consolidation settlements, the elimination of unpromising villages, development of the industry. Further, the post-Soviet economic and social crisis of the 1990s caused irreparable damage to the whole system of reindeer herding methods by crudity of reforming economies in the transition to market conditions. All of these factors dramatically transformed the traditional life support system of the North.

Strengthening political and economic levers of influence on the traditional lifestyle of indigenous numerically small peoples of the North was observed from the 1930s of the twentieth century and wore an avalanche. In the Soviet period, the sustainability of ethnic groups in the North-East was broken as a result of collectivization, socialization of the deer population, policy translation of the nomadic population to sedentary life, the enlargement of settlements, the elimination of unpromising villages, the development of the industry.

From the 1950s began the consolidation of farms, expressed in the transition to collective and state farms construction. In this regard, the growing number of deer, which naturally entailed an increase in the load on the reindeer pastures.

The increase in deer population accounts for the period 1958-1991., the causes of which was the holding of major economic and technological policy of the state, improvement of financing and material support of agriculture, the streamlining of work pieces and prices for deer products, strengthen the protection of property, strict acquisition of herding brigades, the involvement of local industry personnel and send them to work in the far North are well trained professionals from Central universities in the country. The maximum size of the herd came to the end of 1970. - 2463,9 thousand, including breeding stock for $49.9 \%$. It produced 31.8 thousand tons of meat in slaughter weight, per 100 January deers was made of 21.8 kg. meat in live weight.

For all parameters the largest farms were recognized as Yakutia, Chukotka, Yamal-Nenets, Koryak and Nenets Autonomous district.

A huge role in the development of the industry played the opening of a number of research institutions for the study of reindeer herding. Created in the 1930s strongholds zonal stations in different areas of the North (Murmansk, NaryanMar, Salekhard, Bulunsky, Markov) in the outfit, with carrying out of research works dealt with the study and generalization of experience of the best reindeer herding. In 1931 was organized by the Institute of reindeer breeding, which was then transformed into scientific research Institute of agriculture of the far North, which has United all zonal and support units. In the future, based on it was organized by the Yakut Research Institute of Agriculture, Agricultural Research Institute of Northern Urals and Magadan, Zonal Scientific Research Institute of Agriculture of North-East.

The level achieved in the 1970s, remained in reindeer herding areas before 1991, and with the transition to a market economy and reindeer herding economy of Russia were faced with a choice: to be or not to be in the industry.

Later in the post-Soviet period of socioeconomic crisis of the 1990s caused irreparable damage to the entire management system of reindeer herding crudity of the methods of reform farms under transition to market conditions. All these factors have dramatically transformed the traditional system of livelihood of the peoples of the North. 
In the result of ill-conceived organizational and structural changes - privatization functioned effectively large cooperatives of collective farms and state farms, creation of small farms, tribal communities - collapsed system and the technology of reindeer herding, the industry was in deep crisis, and do small people - on the verge of poverty.

In addition, in our opinion, socio-economic and biological factors led to the degradation of reindeer because it is impossible to deny the role of man's impact on the area and condition of pastures.

If in the 1980s of the twentieth century in the Republic of Sakha (Yakutia), the number of reindeer numbered about 380 thousand, while today it is only 161 thousand To the beginning of the transition to a market economy, reindeer herding in the Republic was considered to be highly efficient and profitable sector of the economy. In 1990, in the Republic there were 368 903 deer. Until the 1990s, the safety of the adult population in some areas reached to $97.8 \%$, and business output Mogutov was 75-80 \%.

In the vast expanse of the Russian North has developed a large number of various forms of reindeer herding economy. Among the scientistsresearchers accepted to the division of all reindeer herding regions of Russia into three zones according to the geographic, ethnic and economic characteristics: North-West (Komi-Nenets, the Saami reindeer herding types), northeast (Even, Evenki) and the area of the taiga reindeer herding in Siberia, differ sharply on the current state of the industry, trends in and prospects for its further development. In Russia there are two main branches of reindeer herding: the Samoyedic and Tungusic, on the basis of which arose the Izhma and Chukotka types.

But, unfortunately, it is impossible to talk about a favorable situation to occur today. There is a deepening systemic crisis in reindeer herding (except, perhaps, the Yamalo-Nenets Autonomous District). The system of reindeer herding is based on the year-round maintenance of animals on natural pastures without overfeeding, and does not require large economic costs than livestock. The possibilities for further development of reindeer herding and increase its productivity are poorly realized today.

The historical ethnolocal cases of lifesupport systems of Indigenous Peoples especially highlighted not only through the material, the outside of the interaction, but also through the symbolic side. Conceptual expression of natural and environmental social regulative types of functioning of this system is a ritual and symbolic activities, integrating disparate production (economic) and social practices in a common ethnic picture of the world. The picture of the world and the types of ritual communication are derived not only from the material and practical methods of human activity, but also on the model of socio-environmental interaction.

\section{Conclusion}

These last field expedition studies show a significant deterioration in on reindeer herding in comparison with the Soviet period, as well as a significant loss of grant and reindeer, hunting and fishing traditions of the Tungus (Field materials of the author, 2015: 12).

Reducing the number of reindeer, poor material and technical equipment of the herding camps, paltry wages and herders camp workers, considering the extremely harsh conditions of detention and grazing deer; an urgent "marriage" issue among herders (a large percentage of single men), it is quite understandable reluctance of today's youth to go to the reindeer - all of these factors, coupled with the lack of well thoughtout state policy does not contribute to the development of reindeer herding. If in the 1980s in the Republic of Sakha (Yakutia), the number of 
reindeer was about 380 thousands, today it is only 161 thousand.

For a more complete and rational use of biological resources, recovery of reindeer pastures, as well as identifying a backup it would be appropriate in accordance with the Land code of the Russian Federation to revive the work on integrated assessment, recording, monitoring the condition of reindeer pastures in the whole country. Note that the latest draft land of reindeer pastures, in particular, the former state farm "Kirovskiy" of Kobyayskiy district AAAS was developed in 1979

In our opinion, only the introduction of technological innovations, along with the use of traditional nomadic technologies, the transition to a real family-type communities (reindeer farms) as well as targeted financial support from the state (regardless of the form of ownership of reindeer) will lead to a rise in the development of reindeer herding. Unfortunately, the Federal Law "On the northern reindeer herding", which determines the legal basis for effective and sustainable development of reindeer herding as an integral part of the traditional way of life and culture of Indigenous Peoples, ethnic groups and ethnic communities of the Russian North is not still adopted.

In the Russian Federation reindeer herding is practiced 22 the indigenous people of the North. Reindeer herding is not simply an industry but a way of life of these Northern people. Today, we need drastic political and socio-economic measures for the preservation and revival of traditional sectors of the economy, we need a clear state national policy of the Russian Federation in relation to the indigenous peoples of the North. This requires modernization of the socio-economic and political life of peoples of the North, the adoption of new Federal laws for further development of national relations in Russia.
The humanitarian problems of studying the life support systems of indigenous peoples in recent years also take on a new meaning in the light of an active industrial development areas of residence of indigenous peoples, the need for more in-depth study of the impact on the traditional lifestyle and economic class northerners. Resolution of conflicts arising from the industrial development of the North requires a detailed knowledge of the migration routes of deer from each population. These migration routes determined by the location of seasonal pastures ("hotel" and summer), orientation of the deer on landscape, and traditions of each population. Distance and the intensity of response of deer to the industrial facilities and transport determine the parameters of the construction of pipelines, roads, work of specialized transport.

Obviously, at present we need only state a clear protectionist policy towards indigenous peoples. New socio-economic and political relations in the Russian Federation require entirely new approaches to solving problems of survival of the peoples of the North, their economy based on reindeer herding, hunting season and fishing.

Currently, different ethnolocal Groups of Indigenous Peoples has developed a range of livelihood strategies, which are important not only historical and cultural meanings, but also social and economic factors. Basic life support system focused on the priority of consumer and commercial hunting that supplemented by variability of ethno hardware models of territorial groups and within groups, depending on economic indicators (number of deer). The largest farms use the traditional model of wildlife using is hunting for a sufficient year-nomadic reindeer.

New field empirical material obtained in the course of expeditions, will allow realize processes of transformation in the culture of life support in the North-East of Russia more widely. 
Practical (scientific and social) significance of the research is determined by its actuality, scientific novelty and the conclusions of an applied nature. Its results can be used in the formulation of the general concept of the North, Siberia and the Russian Far East, the implementation of governmental programs and projects, preservation and development of cultural and historical heritage of indigenous peoples, the development of strategy of international / inter-ethnic relations in the region, tourism and other commercial projects associated with the use of resources, ethnic cultures; in teaching and educational activities in the development of courses on ethnography, cultural / social anthropology, theory and practice of intercultural communication, special courses on the history, culture and ethnography of the culture of the North.

Complex research of the culture of life support at the Indigenous Peoples of the NorthEast of Russia, based on a number of theoretical and methodological approaches will significantly supplement the system of scientific knowledge of indigenous peoples and realize the functioning of ethnicity in different political and socioeconomic conditions. Also, this study will create preconditions for scientific forecasting trends in the development of reindeer herding, prompting for further research in this subject area. New field empirical material obtained in the course of expeditions, will allow realize processes of transformation in the culture of life support in the North-East of Russia more widely.

\title{
References
}

Alekseev A.A. (2006). Tekhnologii soderzhania i produktivnost'severnykholeneiv gorno-taezhnoi zone Respublici Sakha (Yakutia) [Technology content and productivity of reindeer in mountain taiga zone of the Republic of Sakha (Yakutia)]. Novosibirsk, Nauka, 128 p.

Field materials of the author, 2015, 1-25.

Willerslev R, Vitebsky P, Alexeev A. (2015). Sacrifice as the ideal hunt: a cosmological explanation for the origin of reindeer domestication. J. R. Anthropol, 21(1), 1-31.

\section{Культура жизнеобеспечения тунгусов: практики ведения оленеводства, современные адаптивные стратегии}

\section{и новые вызовы}

\author{
С.А. Алексеева \\ Институт гуманитарных исследований \\ и проблем малочисленных народов Севера СО РАН \\ Россия, 677007, Якутск, ул. Петровского, 1
}

Статья посвящена изучению актуальной проблемы культуры жизнеобеспечения коренных малочисленных народов Северо-Востока России, в частности традиионной практики ведения оленеводства у тунгусов, рассмотрению современных адаптивных стратегий выживания и новых возможностей в условиях глобализачии. В работе на основе использования метода экспедиционных полевых работ подвергнута научному анализу специфика кочевой 
оленеводческой культуры народов Севера (на примере эвенов и эвенков), которая отмечается структурной однородностью таких явлений, как траектория непрерьвного движения «кормящего ландшафта» (домашнего или дикого животного), путей ичикличного передвижения человеческих коллективов в пределах ареала кочевания и строения хозяйственнофенологического календаря. Пространственно-временные представления, запечатленные в традиционном календаре, также структурно однородны хозяйственному ичилу, строению культуры жизнеобеспечения и отражены в картине мира изучаемых этносов. Оленеводы-охотники, кочевавшие в течение промыслового года по замкнутому круговому марируту, выработали «круговую» модель жизнедеятельности в отличие от «линейного» типа культуры жизнеобеспечения (полуоседлые рыболовы, промысловые пути которых тянулись вдоль главной кормящей субстанции - реки). Сегодня можно говорить о более-менее устойчивой модели культуры жизнеобеспечения коренных малочисленных народов Севера, характерной чертой которой является комбинация и синтез элементов современной (урбанизированной) и архаччной (северной) культур. Проблемная установка определила следующие три основные исследовательские линии: традиционные и современные практики ведения оленеводства в охотничье-промысловой системе жизнеобеспечения у тунгусов, основные варианты хозяйственных моделей жизнедеятельности народов Севера и реконструкиия этнолокальных вариантов жизнеобеспечения у тунгусов. Выявлено, что в настоящее время в разных этнолокальных группах коренных малочисленных народов Севера сложился цельй спектр стратегий жизнеобеспечения, в котором важное значение имеют не только историко-культурные, но и соииально-экономические факторы.

Ключевые слова: культура жизнеобеспечения, оленеводство, малочисленные народы Севера, тунгусы, вмещзающий ландшафт, адаптивность, оленеводческая культура, традиционные модели хозяйствования, локальные варианты жизнеобеспечения, этническая идентичность.

Научная специиальность: 07.00.07 - этнография, этнология и антропология. 